\title{
Nigerian Civil War and Refugee Crisis: The Fate of the Minorities in the Former Eastern Region
}

\author{
Kingdom E. Orji PhD \& N-Ue, Uebari Samuel \\ Associate Professor Department of History and Diplomatic Studies Ignatius Ajuru University Of Education, Port \\ Harcourt Rivers State Nigeria. \\ Lecturer Department of History and Diplomatic Studies Ignatius Ajuru University Of Education, Port Harcourt.
}

\begin{abstract}
This paper examines the fate of the minorities of the defunct Eastern Region of Nigeria in the majority dominated nation-state of Nigeria. The findings show that the Nigerian Civil War (1967-70) was not the genesis of the plight of the minorities. The plight of the minority ethnic groups dates back to the colonial era when the British imperialists merged the desperate kingdoms together to form a federal union known as Nigeria on $1^{\text {st }}$ January, 1914. The amalgamation created a tripartite hegemony which often struggle in a bid to exert control over the state's wealth and resources at the exclusion of the other ethnic nationalities on account of their insignificant number. The researchers argue in this work that one of such conflicts was the 30-months of a cascading gorydebacle called Nigerian Civil War in which the peoples of the then Eastern region were meant to pay high price for everything for being considered minorities. Prior to and during the outbreak of the devastating civil strife the minorities of the Eastern Region were the objects of suspicion, intimidation, distrust, arrest, detention, physical and psychological violence, blackmail, forceful population displacement, killings, inter alia. The paper reveals that these minorities were further confronted with the problems of exploitation, marginalization, forceful enlistment into the Biafran army, hostilities and discrimination in the Biafran Refugees camps and food distribution centres. They became the worst refugees as they were trapped between the retreating Biafran soldiers and the advancing federal troops. Besides, they were constantly accused of harbouring and collaborating with either the Biafra or the federal troops. Hence the massive exodus of the minorities of the then Eastern Nigeria across borders to neighbouring countries like Cameroon, Fernando Po and others which were not only close but also had historical links with these minorities. The researchers conclude by recommending far reaching measures that will ensure and sustain equal representation, fair treatment, true federalism and true justice in multi-ethnic country like Nigeria.
\end{abstract}

Key words: Minority, Majority, Civil War, Refugees, Evacuation and Displaced populations.

\section{Introduction}

There is a general consensus amongst scholars that Nigerian political, social and economic debacles sprang from the defective and faulty foundation the British laid in "uniting" Nigeria (Ogbogbo, 2006; Afolabi 2006, Elaigwu 2011, and Coleman 1958). Tamuno (1980:390) reminds us that "the Government (British) at the time did not seek the views of Nigerians in the two amalgamated territories to ascertain whether or not they favoured such an amalgamation". Thus the different independent and autonomous nations, empires, kingdoms, chiefdoms and so on were forced into a federal union called Nigeria in 1914.

The master stroke of 1914 produced two political jargons: majority and minority ethnic groups, terms which have eventually passed permanently into eco-political and socio-cultural lexicon of Nigeria and Stuck. It is relevant to note as Awolowo (1940) had earlier observed that "certainly these minority groups are at a considerable disadvantage when they are forced to be in the midst of other peoples who differ from them in language, culture and historical background" (Cited in Saro-wiwa, 1989:52). The Hausa/Fulani, Yoruba and Igbo ethnic nationalities were recognized and treated as the majorities while the rest ethnic groups were regarded and treated as minorities. To cement this, three centres of power were established: Kaduna in the North, Ibadan in the West and Enugu in the East. Lieutenant Governors exercised powers in these regions while the Governor resided in Lagos (Ademoyega, 1981: 4). The consequences, according to Ekhator (2012: 46-47) were two prongs. In the first place, it created a tripartite conflict which has affected the goings-on of Nigerian politics till date. Secondly, it poses a challenge to the minority ethnic groups as it was glaringly obvious that independence would be imperial domination by the unholy trinity.

As a matter of fact, it was the determination of the majority groups to maintain the minority 'colonies' which they have inherited from the British colonialists that made them to presumptuously claim all the ecopolitical powers that existed in the country. Saro-wiwa (1989:21) opines:

...ruling Nigeria became, for them, not nation-building but the control of federal power and therefore the resources of the nation. Armed with the power, the incumbents could then seize a disproportionate share of this 
nation's resources for the benefit of their Regions or ethnic groups. The nation was seen as a 'cake' that had already been baked. The sharing of the "national cake" was the pre-occupation of the politicians from the three majority ethnic groups (Ellipsis ours).

It must be placed on record that the leaders and people of the minorities in the former Eastern region had agitated for a separate state - Calabar - Ogoja - Rivers State (COR) - in which they could exercise their liberty and freedom during the colonial era. This was consequent upon the systematic exploitation, subjugation, domination, discrimination, marginalization and short changing suffered in the Ibo dominated region. Justifying the call for a separate state, Naanen (2002:341) contends that "the establishment of regional governments and their control by political parties which identified themselves closely with the aspirations of the dominant ethnic groups in each region intensified the minorities' sense of insecurity and neglect". Hence the agitations for the Benin Delta State (Mid-West) in the Western Region, the Middle-Belt in the Northern Region and the Calabar Ogoja - Rivers (COR) State in the Eastern Region. Although, these states were not created but the Sir Henry Willink led Commission affirmed the fears of the minorities in its report submitted on $18^{\text {th }}$ August, 1958.

Since independence, the previously independent-states, that were subsumed into a larger political entity controlled by three dominant ethnic groups, have continued to experience tangible and deep rooted injustice and genuine inequalities. The internal or indigenous colonialism practiced by the majority ethnic groups has really reduced the minorities to the status of second class citizens. The situation of the minorities in the former Eastern Region was made worse with the desire of the Igbo to continue to lord over them forever. This was clearly expressed in the Biafra Republic which forcefully included these Eastern minorities. The minorities in question were, according to Saro-wiwa (1989:53), the Ijaw, Ikwerre, Ogoni, Ekpeye, Abua-Odual, Etene, Engenni and Ogba of the Delta area and the Ibibio, Annang, Efik, Ejaghan, Uyanga, Umon, Biase, Mbembe, Bete, Sankwala, Utanga-Becheve, Belegete, Yache, Yala, Bekwara, Mbube, Nkim, Ukele, Ejuk, Abanayum, Boki, Ntansele, Etung, Ikom, Olulumo, Ofotup, Akparabong, Nde and Oron of the Cross River Basin and Oban hills areas. Together, these minorities accounted for about thirty-five percent of the total population of the Region. Fortuitously, these minorities were the border communities and major food suppliers to the Igbo people.

The Federal Government's reaction to the declaration of the Republic of Biafra led to the 30 months Civil War which was a tragic and painful conflict especially to the minorities of the Eastern Region. The minorities were polarized between the federal and Biafra lines by persuasion and/or force. In the circumstance, the minorities of former Eastern Nigeria paid supreme sacrifice and patriotism, expensive enough to be paid by the majority ethnic nationalities to keep Nigeria as an indivisible entity. Indeed, the Nigerian Civil War (1967-70) did not only exacerbate the plight of the Eastern minorities but also showcase them as the main victims of the dreadful war. We shall reverse to this later.

\section{Conceptual Clarifications}

There are basically two key concepts that need to be analyzed in this paper. They are refugees and minorities. Seymour - Jones (1992:6) expounds that the word 'refugee' first came into the English Language in 1685 when groups of French Protestants called Huguenots started arriving in England. The French King, Louis XIV, who was Roman Catholic, would no longer allow the Huguenots to practice their faith, so they fled to Protestants England. They were called 'refugees' from the French verb refugier which means 'to take refuge, or seek shelter'. He further argues that by 1780 the word 'refugee' had crossed the Atlantic to the United States. Here, it was used to describe fleeing supporters of the English King George III, in the independence war against England.

Who is a refugee? The new Encyclopedia Britannica (2003: 998) simply defines it as "any uprooted, homeless, involuntary migrant who has crossed a frontier and no longer possesses the protection of his former government". Similarly, the Encyclopedia America (2002:334) says the term encompasses persons fleeing from war, civil strife, famine, or environmental disasters. On its part, the Organization of African Unity (O.A.U now known as African Union) in 1969 views refugees as "persons compelled to leave their places of habitual residence because of external aggression, foreign occupation or domination, or events seriously disturbing public order" (Cited in Encyclopedia Americana, 2002:334). The United Nations Convention on the Status of Refugees (1951) maintains that a refugee is someone who "owing to a well-founded fear of being persecuted for reasons of race, religion, nationality, membership of a particular social group or political of his nationality and is unable or, owing to such fear, is unwilling to avail himself to the protection of that country" (quoted by Seymour - Jones 1992:8). A refugee in this paper will be seen as someone forced against his/her will to seek safety else elsewhere, usually in a strange land, so as to escape political or religious persecution or as a result of a national disaster.

It is instructive to point out, as Helton (2000:63) rightly observed, that massive population displacements were no longer new in world affairs. There are refugees in every corner of the world today. They could be found in the Middle East, Far East, Africa, America, to mention but a few. These developments have been motivated by several factors such as natural disasters like plague, famine, flood, and so on, Government obnoxious policies, religious persecution, war, racial intolerance, among others. However, persons who fled their 
villages in search of help because of environmental factors are called environmental refugee. Mention must be made here of the warning concerning the evacuation of refugees. The United Nations High Commission for Refugees (UNHCR) founded to protect displaced persons makes it abundantly clear that refugees should not be forced to return home if this would place them in danger of persecution. Refugees have the right to apply for asylum and to show the political nature of their plight according to agreed conditions. While their case is being examined they should be treated fairly. Unlike emigrants, refugees do not choose to go to another country. They go because they feel they have no other choice.

Globally, refugee crisis has historical antecedents. For example, the Huguenots, a protestant sect, were forced out of France after the revocation of the Edict of Nantes on $18^{\text {th }}$ October, 1685. King Louis XIV of France's revocation marked the end of tolerance of the French Protestants (Huguenots). Within days Friedrich Wilhelm, the Great Elector of Brandenburg, issued the Edict of Postsdam, offering asylum to the Huguenots (Encyclopaedia Americana, 2002:334, The New EncyclopeadiaBritainica, 2011:998). Also due to racial intolerance the Jews were sent parking from Spain in the late $15^{\text {th }}$ century and the eviction of Jews from Germany, Austria and Sudetenland (now in the Czech Republic) in the 1930s.

There are many cases of politically motivated refugee movements which resulted in the flight of thousands of million refugees across the world. This is true of the Russian Revolution of 1917 and the post Revolutionary Civil War (1917-21) which caused the exodus of 1,5000,000 opponents. Between 1915 and 1923 over 1,000,000 Amernians left Turkish Asia Minor and several hundred thousand Spanish loyalists fled to France in the wake of the 1936-38 Spanish Civil War. When the People's Republic of China was established in 1949, more than 2,000,000 Chinese fled to Taiwan and the British crown colony of Hong Kong. The 1950s were marked by the Korean War (1950-53), the Hungarian Revolution (1956), the Cuban Revolution (1959); and the Chinese take-over of Tibet (1959) among others (The New EncyclopaediaBritainica, 2011:998). In Africa, political persecutions produced the same results. These find expression in the Sudan Civil War (1963 - 1972), Nigerian Civil War (1967-70), Angolan Civil War, Sierra Leone Civil War, Liberia Civil War of 1989, Rwanda Civil War of 1994, to mention but a few. There are environmental refugees in Africa and a typical example was the 1984 famine in Ethiopia. Taken together, religion, racial/ethnic, political and environmental factors have compelled many people to migrate from their habitations to unknown lands thus resulting in astronomical numbers of refugees and displaced persons the world over.

The concept of minority had recently become a polemic and an equivocal one. Donald Young in 1932 adopted the concept of 'minority to refer to groups whose members shared certain racial or ethnic similarities that were considered to be different from or inferior to the traits of a dominant group, and who were thereby 'singled out for differential and unequal treatment (Cited in Peter, 1964). Corroborating this position, Marshall (2011) and Hepbum (1978:1 Cited in Akinyele, 1961:1) aver that a minority group is "a group of people who because of their physical or cultural character, are single-out from the others in a society in which they live for differential and unequal treatment and who therefore, regard themselves as objects of collective discrimination". Suberu (1999:16) sheds more light on this when he posits that minorities or minority groups are culturally distinctive and relatively cohesive groups which occupy a position of numerical inferiority vis-à-vis the major ethnic groups. Farley (1995) believes that a minority is "any group that is assigned an inferior status in society, that is, any group that has less than its proportionate share of wealth, power and/or social status".

In one of his monumental contributions, Akpan (1989:125-125) broadly divides human minorities within a society into social and political categories. According to him:

...under the social category may be included the cultural, religious and economic minorities. Members of this category are usually dispersed within the community. They may-unless constitutionally or legally forbidden to do so - have symbols of common identities, places of regular meetings, and social organizations of selfidentification.... They may be members of indigenous ethnic groups within one country, who occupy definable geographical territories within that country, living among other ethnic groups of different cultures and characteristics within that same country. One has in mind the examples of Igboliving among the Yoruba in the Western parts of Nigeria; the Edo living among the Hausa-Fulani, and so on. Politically, 'ethnic minorities' can be seen from two angles. The first is from the one of socio-political units which indigenously occupies compact and contiguous geographical areas within a policy, as in Nigeria with its 10 major ethnic (linguistic groups of some 250 distinct languages and dialects)... The second angle is that of control of state power and political apparatus through political parties.

Minority ethnic nationality in the Nigerian context seems to locate itself in that which is imputed inferior status and takes the form of systematic exploitation, discrimination, domination and marginalization on account of its small size irrespective of its huge contribution to the stability, growth and development of the country. It is germane to quickly usher in here that there are mammoth cases of 'mini-minorities', 'micro-minorities' and 'macro-minorities' in these minority ethnic groups in Nigeria. In fact, minority ethnic groups in Nigeria are groups other than the Hausa-Fulani, Yoruba, and Igbo with huge political, social and numerical advantage. 
On the contrary, Akpan (1989:128) had argued that "there is hardly any ethnic group in Nigeria, major or minor, which cannot see itself at one point or another as being in the category of an "ethnic minority", adding that it pervades the Nigerian political system and manifests itself in numerical, political or factorial. According to him, factorial refers to factors as trained talents and professionals; the ownership and operation of individual, commercial and other economic enterprises, factors of development in terms of roads, schools, scholarship awards, employment in the public sector, and publicly owned industrial establishment. This claim can be substantiated with ample examples of allegations of neglect, marginalization, suppression, and threat to existence. Saro-Wiwa (1989:176) recalls with relish and incisive articulation that Azikiwe, during his presidential address at the Ibo state Assembly in June 1949 at Aba, spoke of "self-determination for the Ibo" of "national selfrealization" for the Ibo; of "the victimization which is our (Ibo) fate" and most emotively concluded "suffering is the label of our tribe". The Ibo are not done with this claim of marginalization. Currently, they have formed ethnic associations to advance their ethnic interest. There exist the Igbo's Movement for the Actualization of Sovereign State of Biafra (MASSOB), Biafra Defence Force, and Eastern Mandate Union (EMU). The HausaFulani also formed associations to protect their hegemonic interest. The Northern Elder's Forum and the Arewa People's Congress (APC) are notable examples. The Yoruba people were not left out with the formation of the Odua Liberation Movement, the Odua People's Congress (OPC) and the National Democratic Coalition (NADECO).

Our analysis also reveals abundantly that there is what Akpan (1989:129) calls "reversed minorities". This resulted in a situation where the majority ethnic group in a society is controlled by the minority ethnic nationality especially in economic and political spheres. They are heavily represented in all state organs. This is clearly exemplified in the lordship of the minority Tutsi over the majority Hutu in Rwanda. This unique domination had caused several mayhems with dire consequences like the 1959 fratricidal war, the 1994 genocide with the genocidaires forming the bulk of the refugees, just to mention but a few. No doubt, there exists wide disparity in the majority - minority relations. Yetman (1991) is quick to point up that since the 1930s, the term 'Minority' has been used to denote social groups that are oppressed, stigmatized and discriminated against based on ethnic, racial, biological, cultural, religious and other characteristics. Stavenhangen (1983:122) vividly testifies that the exploitative relationship which often characterizes the interaction between the minority and the majority ethnic groups can take the form of "unequal regional development (which ethnic groups are geographically localized) or of differential access or different forms of segregation and discrimination in social economic and political life". Barron (1967) correctly contends that in the course of their interaction, the dominant group tends to assign a definite minority status to the subordinate groups and to consider them as outsiders or those of the periphery. The condition is exacerbated when, as Osaghae (1994) asserts, the majority assumes the 'natural right to dominate, control and direct the activities of the state to the exclusion of the minorities which produces the wealth of the state as in the case of Nigeria and this becomes a constant source of opposition by the minority groups. Simpson and Yinger (1963:28) aptly described the relationship between the majorities and minorities as parasitic, oppressive and unequal. In their words: "when fate has cast two people upon the same territory, one must inevitably be the hammer and the other the anvil". Accordingly, the minorities of Nigeria especially those inhabiting the former Eastern Region of Nigeria became the 'anvil' upon which the Nigerian Civil War (1967-70) was structured and the majorities became the strong 'hammer'. The power play between and among the majorities during the period under review made the minorities the actual victims whose fate is yet to be determined forty three years after they were traumatized and brutalized. What is of note is that it is the business of this paper to explicitly demonstrate how and why the wealth and minorities of the former Eastern Nigeria were manipulated by the majority ethnic groups, the principal groups, to their advantage in a political debacle that had kept them the most oppressed people of the world.

\section{The Nigerian Civil War and the Majority - Minority Politics}

The clashes of majority interest and principles coupled with the feud between the two principal actors Gowon and Ojukwu - have been largely attributed to the major causes of the war that ravaged the country for 30 solid months. Little or no attention has been given to the urge and desire of the two main actors from the majority ethnic groups to control the oil wealth of the minorities living in the former Eastern Region of Nigeria. It is historically plausible to argue that the region was declared a theatre of war where the indigenes were 'bruised, battered and bloodied' because of their God-given wealth. Leo (1975) has given the hint that distribution of wealth and resources is a very important factor in either fomenting or taming of conflict in the society. Oil politics was, indeed, central to the execution of Ojukwu's dream of Biafra and Gowon's pursuit of 'One Nigeria'.

This paper reveals that the desire to control the petrol dollars in the minorities' territories of the former Eastern Nigeria that compelled Ojukwu on May 27, 1967 to unilaterally declare the secession of the Former Eastern Region and christened it "The Republic of Biafra". Queerly enough, Ojukwu excluded the minorities in this region and chanelled all the political and economic power to himself and his people. Ademonyega (1981:177) states pungently: 
...He (Ojukwu) arrogated all power will, decision and direction to himself... other Nigerians meant little or nothing to him - he could do without them - as soon as he got all he wanted from them... at the same time, he seemed to have ignored the fact that the Eastern Region did not consist solely of the Ibo people. If the Ibo were prepared to go the whole hog with him, how about the non-Ibo - the Ibibio, Efik, Annang, Ogoja, Ekepeye, Ogoni, Abua, Odual, Ijaw and Engenni? (Ellipsis ours).

The point has to be made here that oil was discovered in commercial quantity in Oloibiri, Ogbia Local Government Area of the present day Bayelsa state in 1956. By the outbreak of the Civil War, the black gold has been discovered in many parts of the former Eastern Region. This is true of Bomu (1958) Afam, Korokoro and Ebubu-Eleme in the early 1960s. Other oil fields were found at Bodo West, Yorla and Lubara Creek (N-Ue, 2012: 17). Other discoveries were made in other communities. Before the war, oil has emerged as the dominant revenue earner for the Nigerian Government. Nigeria's crude oil production contributions to the national economy between 1960 to 1970 revealed a steady increase from $\$ 8.8$ million in 1960 to $\$ 139.2$ million in 1965 and to $\$ 510.0$ million in 1970 (Ikein, 1991:267). In Saro-wiwa’s (1989:53) view “Almost 94\% of the Region’s crude oil production before the war came from the non-Ibo sections of the Region". It must be added that the minorities' oil revenues became the main pivot around which Nigeria's foreign policy, development objectives and growth targets are constructed, implemented and executed. Ogbemudia (1991:81) masterly paints the picture clearer when he tersely remarked that "By 1968, oil production in Nigeria had reached the twenty million ton mark, and an estimated fifty million ton mark by the seventies was a just expectation. As most oil installation and, at least, two well known sea ports were in the former Eastern Region". Ojukwu is entitled to the royalties by the shell-B.P operating in Port-Harcourt and Bonny if he continued to maintain his firm grip on his Biafra's kingdom.

It was against this backdrop that Ojukwu took practical step to control the oil revenue. He immediately promulgated the Revenue Collection Edict 11, 1967 which stipulated that "any revenue due from any source whatsoever in Eastern Nigeria and collected in Eastern Nigeria for or on behalf of or payable to the federal Government... shall be paid...to the Government of Eastern Nigeria". By this directive, all oil revenue in the East estimated at N2, 000.000.00 should be paid to Enugu instead of Lagos (Ogbenudia, 1991:82, Ademoyega, 1981:187). Little surprise, that when Port Harcourt was liberated by the federal troop, he (Ojukwu) retaliated by placing the General Manager of shell-B.P company, Mr. Stanley Gray, under some form of arrest. When this attempt yielded no tangible result, he went further to confiscate all shell-B/P installations in his kingdom and placed them under a Petroleum Management Committee headed by the late Professor EniNjoku (Saro-wiwa, 1989:98-99).

Gowon who was also quick to realize the emerging importance of oil in the economy wasted no time to carve out two states out of the minority ethnic groups in the former Eastern Region. Thus he created the Rivers and South-Eastern states with headquarters at Port Harcourt and Calabar respectively on $27^{\text {th }}$ May 1967. Okigbo (1989:201) avers that it was calculated to give a sense of identity to the minority groups in Eastern Nigeria in relation to the Ibo majority around them. This position was shared by Ademoyega (1981:187-188) who held that “...the Federal Government announce that it would take 'stern measures' against the Eastern Region. These were economic, political and diplomatic measures. At the same time, Gowon threatened to use force to protect the minorities, if the East seceded".

Our investigations revealed Gowon's interest to create the two minority states out of the Eastern Region and the threat to protect them was borne out of the desire to control oil in these areas. As argued above, the oil profile was rising steadily in the economy of the country. The federal government could not afford to miss oil royalty payments from the Nigeria's main oil company; Shell-B.P. Saro-Wiwa (1989:98) has argued persuasively that:

If Ojukwu got paid the royalties for the half-year ended June 1967, his exchequer would not only have swollen, he would also have had considerable foreign exchange at his disposal to enable him pursue his war aims with great vigour. One retains a niggling suspicion that Lagos might have been informed that if she did have some presence in the oil areas of Eastern Nigeria, there might be justification for paying the royalties, whereas if Ojukwu continued to control the entire oil region, he would have a right to the royalties, since possession in nine parts of the law.

Gowon successfully recovered the crude oil installations in the minority states and used the proceeds to execute his policy of 'one Nigeria' to a logical conclusion. The taken over of Bonny, Calabar and Port Harcourt turned the table against the secessionist Biafra. In another sense, Gowon in the words of Achebe (2012:210) "had succeeded in cutting Biafra off from the sea, robbing its inhabitants of shipping ports to receive military and humanitarian suppliers". Of sentimental importance was the transfer of the ownership of oil wealth from the owners- minorities to the majorities. This was provided for by the promulgation of a degree on $1^{\text {st }}$ April 1970, modifying the system of revenue allocation in favour of the majority ethnic groups. In the light of this, the Nigerian Civil War did shape or reshape the nature of Nigerian politics in favour of the minorities for the sheer 
insensitivity of the federal Government to the Eastern minorities; Saro-wiwa (1989:238) became irascible and submitted that:

We (Eastern Minorities) were to know that, far from being a war of unity, the war was being fought by the three old adversaries for the oil wealth of our areas and that we were to be bruised, battered and bloodied and left to flounder helplessly in a darkling plain in an uncaring, ignorant country.

The minorities were further meant to declare their unalloyed patriotism and pay supreme sacrifice with the granting of state Pardon to one of its son, Isaac Jasper AdakaBoro. Although, political detainees like Chief ObafemiAwolowo, his followers and Dr. M. I. Okpara and his colleagues were granted amnesty but the remission of the death sentence of Boro and his lieutenants Samuel Owonaru and Nothingham Dick endeared Gowon to the minorities. The old war-horses of the minorities like chiefs Murphy and E. O. Eyo from Calabar - Ogoja, and Chief Harold Dappa-Biriye, Ken SaroWiwa, Wenike Briggs, from the Rivers area, among others therefore supported the federal with the hope of a better future for the Eastern minorities. Nabo B. Graham-Douglas in his work: Ojukwu's Rebellion and World Opinion captures this prism when he undermined the case of united Biafra and asserted the autonomy and desire of the ethnic minorities in Eastern Nigeria to remain within United Nigeria where they felt they would be able to realize their legitimate aspirations rather than stay in Biafra where their land would be regarded as a natural lebensraum by the much more numerous Igbo whose treatment of the minorities in the past and even during the war, had left much to be desired (Cited in Osuntoku, 1989:88-89).

In retrospect, Isaac, Jasper Akaka Boro waged a war of independence against Major-General J.T.U. Ironsi on $23^{\text {rd }}$ February, 1966 by declaring the Niger Delta Republic and a state of emergency. The Twelve-Day Revolution, which was to bring the Ibo domination, neglect, intimidation and oppression to a logical end, was prevented from becoming a reality. Consequently, Boro and his two lieutenants were on June 21, 1966 sentenced to death by Justice John Philip Ebosise, presiding at the Port Harcourt High Court after a marathonic sixty days trail. Major-General Gowon magnanimously commuted their death sentences to life imprisonment and later granted them complete remission of their sentences (N-Ue, 2012:178). To reciprocate this kind gesture and to find a place for his beloved people after the war, Boro joined the Nigerian Army's Third Marine Commando as a Major and made brave exploits, leading to the liberation of most minority ethnic groups like Bonny, Asaba and Port Harcourt in the then Eastern Nigeria. Saro-wiwa (1989:170) beautifully writes of Boro, "He... alone had volunteered to make the dangerous crossing from Egwanga (now IkotAbasi, Akwalbom State) to Kono (Ogoni, Rivers State). He has taken Opobo, Nkoro, Kono and Okirika". This was not surprising as most federal combatants in the 'Tiger claw Division' knew next to nothing of the critical Knowledge of Niger Delta terrain (Enemugwem 2002: 353, Nwajia Ku-Dahou, 2008: 324) while Isaac Boro knew every inch of the Niger Delta region as an indigene and as a former police officer who had served in the region. The minorities were denied this special gift and messiah when he was shot dead in action on his way to Bodo (Ogoni) from Okirika on $17^{\text {th }}$ May, 1969 shortly before the war ended (Saro-wiwa 1989:170, Naanen 2002:347).

His untimely death provoked wide condemnation and much controversy. A strand of this argument has it that Boro was murdered by his commanding officer, Col. Benjamin Adekunle (Known in the military circle as "Benjy"). He was said to be jealous of Boro's rapid promotion to the position of 'Major' (Obasanjo, 1980 cited by Nwajiaku-Dahou 2008: 325). If this is anything to so by, it seems probably to infer that it was a calculated attempt by the Majority to exterminate the minority from the corridor of power or position of considerable influence.

To also prove that it was the game plan of the majority to render the minority powerless, the Ibo at the incipient stage of the war rendered the minority ethnic groups of the Eastern Region defence less, impotent, confused, dejected and disunited. From the account of Akpan, it can hardly be contested that a significant number of both "official" and "unofficial" actions were for the above stated purpose against the minorities. According to him, the first "official action" was to employ their "divide and rule" tactics as a way of weakening the attraction and demands of state creation as well as breaking the very basis of their bond of solidarity and unity of purpose among the minority ethnic groups. They attempted to persuade the minority ethnic groups that their political aspirations would be satisfied within the confines of Eastern Nigeria rather than in the federal Nigeria. It is most heartening to note that another 'Official Actions' taken against the minorities was the policy of disarmament. Akpan (1989:138-139) tells us quite bluntly:

Before the start of hostilities, the "minorities" were systematically disarmed by the police. They were discriminately compelled to hand in all forms of weapons short-guns. It became, for them, an offence to own or posses any form of weapon. The same treatment was not extended to members of the 'majority' ethnic group, who were in fact known and seen to be openly importing and manufacturing arms for themselves... they saw themselves as not belonging, and started to suspect and lose faith in the Ojukwu military Government.

The "unofficial actions" took the forms of blackmail, falsehood, and the arrest and detention of real or perceived "saboteur", invented to settle old squabble between the minority border territories and the majority ethnic groups. As far as the Biafrans were concerned, "all members of the minority ethnic groups were potential saboteurs. 
Military failures were caused by saboteurs. The worst federal air raids were guided by saboteurs". This exposed the minorities as the main object of "mob justice" and the real victims of the war.

It must be placed on record that most personalities from the minority ethnic nationalities contributed immensely to the 30 months old Republic of Biafra. For instance, Chief Ntieyong U. Akpan served Biafra meritoriously as the Chief Secretary before and during the Civil War years and Major General P. Effiong, who ostensibly mid- wifed the unity of Nigeria when he surrendered Biafra to Nigeria on January 12, 1970, served Biafra as the Chief of General Staff. Other prominent minority elements from Ogoni who made tangible contributions were ex-parliamentarian Chief Hon. KemteGiadom, Chief E.N. Kobani, Dr. Garrick BarileLeton, Mr. I.S. Kogbara, Mr. Peter Akere, Mr. Pius DornuKinako, among others. Our investigation reveals that Mr. Ignatius Kogbara who read Political Science and History from the University of Leicester, England in 1960 served as Biafra's Ambassador in London. He therefore formed the nucleus of what Achebe (2012:160), aptly described as the Biafra diplomatic service whose duty included the framing of the "Biafra argument". Mr. Pius DornuKinako dutifully served the Biafran secessionist Government as a senior officer in the Ministry of Agriculture, Mbawi in Aba and Dr. G. B. Leton who obtained his doctorate in Analytical Chemistry from University of London in 1963 served as a Lecturer in Physical and Modern Inorganic Chemistry Department of the University of Nigeria, Nsukka (1963-1970). The genius must have served in the Research and Production Units (RAP) and contributed to the making of the Igbo unique and notorious war machine, Ogbunigwe (which literally means "killer in groups"). Nwankwo (1980:29) says "it killed in large numbers and when used, could kill as many as sixty people". In spite of these huge contributions, the minority ethnic groups were discriminated against, massacred, rejected and abandoned to their fate.

\section{The Nigerian Civil War and the Minority Refugees' Crisis}

The fate of the Eastern Region minorities was again left hanging rather loosely in the balance in the refugee's crisis of the majority dominated Nigeria. History has it that the first well established case of refugee in independent Nigeria dates back to the first military coup d'état in the political calendar of the country and this took place on $15^{\text {th }}$ January, 1966. This military coup d'état claimed several lives and forced about 2,200 to migrate across the Nigeria-Bénin Border to neighbouringBénin Republic for security and safety purposes. The refugees who refused to return home for fear that their political 'enemies' would prey on them were persuaded and repatriated home after intense negotiations with the Beninois Government. The returnees were about 2,300 (Mohammed, 1989:236). Accordingly, the Nigerian Red Cross society was effectively mobilized and they offered essential humanitarian aid to the refugee in Cotonou. The services of the Nigerian Army and Nigeria Police were procured and these helped to facilitate the repatriation operation to Ibadan and other towns in the Western Region. It is deducible from the above that the refugees who were mainly involved in this first mass exodus movement were the majority Yoruba living in the western part of Nigeria.

However, the eruption of bestial massacre of thousands of peoples of southern Nigeria especially the people of the former Eastern Nigeria in the Northern towns of Zaria, Kano, Gusau, Funtua and Sokoto actually captured the essence of this paper. The countercoup of July 1966 which was like a retaliatory move unfortunately went too far and degenerated into the mass killings, looting and burning of August and September of 1966. The tensed situation was further infuriated with the news of the killing of the northerners, living in the Eastern towns of Enugu, Onitsha, and Port-Harcourt. Mohammed (1989:237) reminds us that from the end of September to the end of October 1966, there ensued a mass movement of people from the North to the South, particularly to the East and Mid-West. Over one million displaced persons were evacuated from the North to the South during this period of only one month. Of these figures, there were 12,000 refugee railway employees alone (Forsyth 2011:81).

The roles of the Nigerian Red Cross and the Nigerian Airways made the Easterners to escape the sharp edge of the daggers of the bellicose Northerners. While the Nigerian Red Cross readily provided emergency and humanitarian services, the Nigerian Airways provided free airlift of relief materials from Lagos to designated centres of the victims of the massacre in Kaduna and Kano.

Ademoyeya (1981:183) opines that it was the report of this fresh outbreak of 'pogrom' against the Ibo that made civil war inevitable. The pogrom, no doubt, drove the regions poles apart and resulted in the secession of the Eastern Region on May 27, 1967 which Ojukwu prefer to call the "Republic of Biafra". By taking this action, as Achebe (2012:92) sharply observed, "Ojukwu had committed us to full-blown war. Nigeria would never be the same again". Perhaps, it was against this background that the Biafran War Lord, Lt. Col. Ojukwu had consistently maintained that "the Biafran people never declared war on Nigeria. Rather, they reacted in selfdefence and continued reacting in self-defence until it was impossible to continue" (Ojukwu 2011:179).

The point to note here is that minorities of the Eastern Region were killed mercilessly as Ibo people in the North because of ignorance. There are several bulks of Nigerian population who are yet to know that in Eastern Nigeria there are ethnic nationalities other than the Ibo, or that there were minority ethnic groups other than the dominant Hausa/Fulani in the north. It needs to be stressed that all the inhabitants of the former Eastern Region 
were not all Ibo people so also those killed, harassed, maimed, and brutalized in the north. The minorities of the Eastern Region became the 'scape goat' of the majority - Hausa/Fulani and Ibo - power play. Sadly enough, they were discriminated against in the scheme of things even when they (i.e. minorities) contributed hugely to the Defence Fund. The Fund was the Eastern Government grand design to raise financial support for the purpose of rehabilitating the evacuated Easterners who fled the north. As it were, there was the need for housing, hospital, job opportunities for employees who have been forced to become unemployed and other resettlement problems. To check this short - changing, exploitation and discrimination, a group of the leaders of the minority peoples of Eastern Nigeria led by chief E.O. Eyo petitioned Major Hassan U. Katsina, the Governor of Northern Nigeria, to bring his force into Eastern Nigeria in order to free them from the clutches of the Ibo (Ademoyega (1981:180).

The fate of the Eastern minorities was further tossed at the outbreak of the Civil War on Thursday July 6 , 1967. As discussed above, the minorities were treated to doses of intimidations, psychological and physical violence and systemic exploitation before the hostilities kick-started. But after the start of hostilities and in the course of it, the minorities in the Eastern Region became the stark objects of blackmail, forceful population displacements, killings, suspicion, surveillance, distrust and embarrassments everywhere in the region. As Akpan (1989:139) puts it frontally "They were indiscriminately harassed, abused and assaulted at the ubiquitous checkpoints which littered the region. The only passport to some form of respect was the ability to speak the Ibo language". Ogbemudia (1991: 74) agrees that the new order brought sorrow to many families, and untold sufferings to millions of Nigerians, especially the minorities. This was the price they must pay for their insignificant number in a country mostly dominated by majority ethnic groups.

As the conflict dovetailed into a large scale war, the minority border communities were forced to massively cook for the forces each day. This did not deter them from looting and raiding the border communities for money, wine, food and women. More important, the minorities of the territories were coerced into the Biafran rebel forces like the Combat Units, Militia bands, and many others. In fact, forceful conscription into the Biafran Army became the order of the day when the grass could no longer fight. Peter Akere, an Ogoni minority refugee in the Ibo heartland, vividly testifies that:

A contributory factor toward conscription was the awareness on the part of rebel soldiers themselves that illequipped, rag-tag, hungry and unpaid as they were, Biafra was not worth fighting for. Initially, it was possible to resist 'Police action' with machetes and hope to return with "ten Hausa heads". But with the declaration of total war, and in the face of an army which, realizing the folly of its past mistakes of softness, was determined, fortified with every material and moral encouragement, to crush the rebellion, it became unthinkable to regard battle as a wrestling match which one could engage in without arms (cited in Saro-Wiwa, 1989: 197).

Added to the above problem of lack of modern war equipment, and better remuneration was the issue of what they chose to call "No.6". The "idea was that self-preservation must take precedent over Biafran survival and not the latter over the former as had been the case". In fact, to the amazement of the Biafran Personnel Department, Statistics Division of the Army Headquarters, (variously situated at Enugu, Owerri and Umuahia according to the tide of the war). It was discovered that "there were more soldiers on paper than were available for deployment". Hence, the adoption of conscription of minorities as a main policy of recruitment to fill the blank spaces (Saro-Wiwa, 1967:197).

By the end of 1967 and middle of 1968, the minorities had been pushed out of their own homes by the secessionist Biafra. The reason was the advancement of the Federal Government forces who were recapturing 'their' territories. The natives were to meet atrocities and cruelties of the highest order. Akpan (1989: 139) supports that:

As the war progressed and worsened, as the Federal troops over-ran one minority areas after another, because the minorities constituted the border territories, the inhabitants of any such area were automatically suspected and accused of collaborating with the enemy by either aiding their infiltration or locally harbouring them. The retreating Biafran soldiers would not only wreak as much havoc on life and property, but would forcefully carry away women and children into enforced refugee camps. Many starved and died there in the course of further continuous movements as their camps were threatened by the advancing Federal troops.

The order to evacuate from the advancing Federal side, as Peter Akere aptly noted, was immediately backed up with force and as men and women were evacuated in Government vans, army personnel were carefully and systematically supervising every inch of the evacuation to make sure that it was thorough (quoted in SaroWiwa, 1989: 190). It is also instructive to say here that most of them were not so lucky especially those fleeing from evacuation, arrest, detention, torture and /or forceful conscription into the Biafran army. This category suffered and consequently met their untimely death as they embarked on a hazardous journey without known destination, adequate preparation and guidance or directive. They died in their numbers as they were not advised by the Civil Defence Corps to take cover in the bushes during air raids or privileged to hear the public safety warning issued by the Biafran Government. Achebe (2012: 190) reveals that "the Biafran Government had issued a public safety warning to all citizens to abstain from wearing clothes of light colours like white or cream or sharp colours such as orange, purple, or red that could be easily spotted by the Nigerian Air Force". The resultant 
effect was the high mortality rate of the minorities. One was the Ogoni ethnic nationality of which Saro-Wiwa (1989: 199) estimated that about thirty thousand which were over ten percent of the total population of the ethnic group was lost to the Biafran onslaught. They were to pay heavily for allowing their territory to be used by the Federal troops as well as the anti-Biafra activities of their leader K. B. Saro-Wiwa. At the onset of the war, SaroWiwa was an informed personality so he sneaked through Bonny to Lagos to declare the loyalty, solidarity and support of his people to the Federal Government's cause of "One Nigeria".

The survivors of the evacuation saga were sent to the Food Distribution Centres and Refugee Camps located in Ibo villages like Mbieri, Nsu, Mbano, Aba, Orlu, Ngwa, Umuahia, Enugu, Aboh-Mbaise, Ohaji farm settlement among others. Achebe (2012: 169) throws more light on the establishment, location and structure of these Biafra refugee camps when he luminously informs that:

There were many Biafran refugees' camps dotting the landscape, from Enugu in the North to Owerri in the South, during the thirty months conflict. Many held between a few hundred and a few thousand people. At the height of the war there were well over three thousand such centres and camps a great number but woefully inadequate to the actual need. These camps were often hastily constructed tent villages set up beside bombed-out churches, in foot ball or sports arenas, or in open fields in the forest. They uniformly lacked electricity, running water, or other comforts.

The Camp Government or Administration was headed by a Director which of course was an Ibo man, an ardent supporter of Biafra. He was supported by a handful of other Ibo ancillary officers like store keepers, wardens, welfare officers and security officers. They together formed the policy making body in each camp. They were also to give an account of the refugees, deliver aid, and control food distribution. Each Minority Group that cohabited together with other ethnic groups had its own leader and the family heads that were to assist the group leader (Anokari, 1986: 156). This implies that the organization was based on a divisional basis. Besides, there were oppositions and lack of understanding from the indigenes who claimed that they had never benefited from the Eastern Government and so they will not share their hard earned resources with the displaced minority people. The condition of these minorities was made worse in these camps as they were labeled saboteurs. This provided them ample opportunity to pilfer their little belongings.

Although, the minorities who were influential on the Biafran side greatly contributed to the survival of their kith and kin, who were like them, forced against their will to live as refugees but corruption and ethnicity left the previously healthy, strong, wealthy, promising people wretched, pale, hungry, malnourished and poor. Kwashiorkor, which is defined as the absence of protein in the diet, and the outbreak of epidemic disease like diarrhea, cholera, to mention but a few, took a great deal of advantage of the minority traumatized population. There were rampant and obvious cases of misappropriation and diversion of the relief materials donated by the sympathetic World Relief Agencies and Voluntary Organizations to ameliorate the sufferings of the refugees found in the Biafran enclave. Peter Akere (cited in Saro-Wiwa, 1989: 195-197) gives us an insight ". . . Army officers had their own special share of anything that was brought in. Kwashiorkor clinics and feeding centres were established ostensibly to drain into private hands the food that was assigned to refugees... They then swooped on relief food, articles of clothing and money and diverted as much as pleased them to private use, not minding the plight of those for whom those things were intended. The most lucrative appointment then was Camp Director and it was given to the highest bidder. Once appointed, he would normally hasten to recover the money spent on obtaining his post". The minority refugees were at the receiving end of all these because they were powerless victims of circumstances. There is the likelihood that they occupied the camps Achebe (2012: 170) meant when he said "other camps could only be described as deplorable-epidemic ridden graveyards. In these camps the combination of poor sanitation, high population density, and shortage of supplies created a bitter cocktail of despair, giving rise to social pathologies and psychological traumas of all kinds-violence, extortion and physical and sexual abuse. In sum, the camp experience of the minority ethnic groups in the majority Ibo Biafran enclave was not far from Seymour-Jones (1992: 25) findings. He had succinctly established that:

(a) Health risk is rampant in camp populations as they are exposed to disease.

(b) There is unemployment as there is often no work for camp populations.

(c) Dependency rate is high as camp populations lose control over their own lives.

(d) The camp populations are exposed to local hostility. Local communities disliked camps in their midst, which strain local resources. Integration into host country is more difficult in camps.

On a broad level, the Federal Government's economic blockade and "starve them into submission" policy (Achebe, 2012: 210) had a remarkable impact on the secessionist Biafran. The Federal Government was angered by the increasingly double standards of the foreign relief organizations especially the activities of Dr. August Lindt of the International Committee of the Red Cross (ICRC). For this reason, he was declared persona nongrata and the Federal Military Government decided to take personal delivery of the aid. It was revealed that these international agencies like Oxfam, the International Committee of the Red Cross or Red Crescent based in Geneva, African Concern, the French Red Cross Caritas International based in the Vatican, Joint Church Aid, the Catholic Relief Organization, the World Council of Churches, to mention but a few, aided the penetration of arms 
and ammunition as well as food to the Biafran soldiers since the food carried to the enclave only went to strengthen the soldiers rather than the suffering and dying masses (Elaigwu, 2009: 188-189, Mohammed 1989: 235). The dire consequence of this action was acute food shortage which invited the merciless claws of hunger. More than three million Biafrans including children died in Biafra (Achebe, 2012: 226). And on a more serious note, starvation helped to bring the 30 months of a cascading blood basin to an unofficial end. Nwankwo (1980: 68) remarked that " $\ldots$ the mid 1969 many soldiers died on their foot, shooting... They were killed not by bullets or shells, but by hunger".

It is also shocking to reveal that after the minority, especially elements like Lt Col. Phillip Effiong and UkpabiAsika, a former Social Science Lecturer at the University of Ibadan, assisted the Federal side to bring about the return of peace to the war-torn country, the Gowon's Amnesty as found in "No Victor, No Vanquished" and the 3R-rehabilitation, reconstruction and reconciliation which followed was never extended to the minorities. Little or no attempts were made by the Federal Government to really integrate these minorities even as our analysis has shown that they were really the victims of the bitterest conflict in West Africa. The people of the border communities who were cruelly evacuated to the Biafran heartland as refugees were never taken into consideration. Most of the minorities were assisted to return home, courtesy of the generosity of their fellow minorities. Anokari (1986:159-160) discloses that: the Ogoni returnees on their journey from Mbieri, Mbano, Mbaise and other hinterlands were given express permission by the Efik, Annang and other neighbours not only to pass and settle but also make use of some of their available social facilities like school, farm settlements and transport. Saro-Wiwa (1989: 229) regretted that nothing has changed, not even the lessons of the Civil War, the politics of majority in Nigeria. His view is very remarkable and illuminating here "In the tradition of the old politics where only the majority matter and latter behave as though all others were mere appendages, the overwhelming attention was paid to the Ibo. and the Ibo problem overcame everyone else's problem".

\section{Nigerian Civil War, Minority Refugees and Neighbouring countries.}

Like the First World War (1914-18), the Nigerian Civil War (1969-70) brought flood of refugees which are mainly minority border communities especially in the present states of Rivers, Bayelsa, AkwaIbom and Cross River States to wander across the borders of Biafra (now Nigeria) to neighbouring countries like Cameroon, Fernando Po, an Island, which formed part of the Spanish Empire and later Equatorial Guinean when the later gained independent in October, 1968. As stated earlier, the minorities experienced intense fear or repugnance before and during the dreaded Civil War, hence, the movement of the border communities to seek safety and security across the Bight of Biafra (now Bight of Bonny). During this time of forceful evacuation, any form of makeshift transport was used to ferry their remaining possessions. It was possible for the displaced populations to have migrated without any meaningful possession. Needless to say that some of the refugees crossed the border in order to escape being conscripted into the Biafran army. However, in most cases, some roam the rivers, valleys, rivulets and many others in search of help.

It has to be documented that certain factors were at work to make this escape, migration and movement possible. The first was based on historical factors. The minorities have for long established historical economic ties with the peoples of Cameroon, Fernando Po, Equatorial Guinea and Santa Isabel (N-Ue, 2012:81). This took the forms of trade and fishing activities. It was the practice of the minorities occupying the southern part of today's Nigeria to find fortunes and exploits in the above mentioned countries. The fisher-folks also migrated along with fishes into these countries. This contact was facilitated by the locally dug-out canoes which bridged the short distances between and among these peoples. Mahadi (1989:267) stipulates that "the Island of Fernando Po lies less than 125 miles south of Eastern Nigeria". Okoro (2002:97-98) attests that the distance from Calabar in Cross Rivers State, Nigeria to Equatorial Guinea is a few Kilometres. The former Bight of Biafra (now renamed the Bight of Bonny after the Nigerian Civil War) extends from the estuary to Guinea. Many native Bube and settler (Creole) as it was formerly called share common affinity with some Nigerian peoples, especially Eastern Nigerians. No doubt proximity, strong cultural affinity and historical economic relations coupled with their kith and kin still residing in these countries made their movement from the clutches of bloody civil strife easier.

The European imperialists also grafted their forced Labour Policy on the already established relationship. N-Ue (2012:77) discloses that in 1923 a treaty was established between the Spanish Government. The purpose of the Treaty was for the Nigerian Government to provide labour to plantation in Fernando Po. By 1929 the Fernando Po forced Labour law has been enacted. The colonial Government of Nigeria received commission for any number of labour supplied. Interestingly, most of the Nigerian workers were recruited from Oweri, Calabar and Ogoja (Fadeiye, 1978: 140). As West Africa (1960:1271) revealed "the immigrants from Eastern Nigeria far outnumbered the indigenous population". N-Ue (2012:78) argued that due to their dominant population all the immigrants were called "Calabar boys". For the minorities, these nieghbouring countries were a sort of home away from home. 
The point has to be made here that the minorities of former Eastern Nigeria also formed the nucleus of the large scale influx of Nigerians into the Southern Cameroons: By 1954, following the Post-war expansion of the plantation industry, some 25,000 men were employed in the Victoria plantation, and 6,000 or 7,000 were employed in Kumba division (Mahadi, 1989:254). What is to note is that the English-speaking Cameroon, formerly known as the Western Cameroon, was a part of Eastern Nigeria until 1962 when Western Cameron opted to join Eastern Cameroon after a referendum (Okoro, 2002: 94-95). These colonial economic and political relations continued to foster unity between these peoples in the post colonial era.

Upon the attainment of independence on $1^{\text {st }}$ October, 1960, the Nigerian Government as well as the State Governments of former Eastern Nigeria has continued to maintain and strengthen these pre-colonial and colonial relationships which were of immense value till date. There are many of these minorities still living and doing legitimate business in Cameroon, and Equatorial Guinea. In addition, the University of Calabar, Nigeria has trained many medical doctors from Cameroon. There is also evidence of bilateral educational exchange progammes for students and lecturers of institutions of higher learning in these countries (Okoro, 2002: 96). Other evidence of economic and socio-cultural ties have continued to be sustained in the post independence era. The large scale movement of Eastern Nigerians to and fro Fernando Po led to the development of Annual Sports which were organized between Fernando Po and Nigeria's Eastern Region and was financed by the Spaniards. Perhaps, this could be a way to appreciate the huge Nigeria's cheap labour contribution (Mahadi, 1989:255). Until recently, Eastern (now Southern) Nigerians which the former Nigerian Ambassador to Equatorial Guinea, Navy captain Festus Probeni speculated to be about 60 percent, controls the commercial activities of the Equatorial Guinea. What is more, Nigerian Government has continued to strengthen her cordial link with Equatorial Guinea with the establishment of a school for the training of Nigerian children in Equatorial Guinea, Nigeria has further cemented the ties by providing air services to Equatorial Guinea through Calabar and Port Harcourt international Airport (Okoro 2002:99).

Reflecting on these and many other historical links, the Governments of Cameroon and Equatorial Guinea played pivotal roles during the Nigerian - civil war in order to bring about lasting peace in the war- torn country - Nigeria. This was showcased in the sympathetic manner and feeling which they expressed and reviewed the political impasse in Nigeria. A pointer to show their support for Nigeria was Cameroon's nonrecognition of the rebel's independence as Tanzania, Ivory Coast, Gabon, South Africa and Zambia did. The president, Ahidjo, went further to take active part in the OAU's (now AU) efforts to reconcile Nigeria and Biafra. He was the foremost initiators of the Kinshasa Resolution. He collaborated with President Mobutu of Zaire to deny the rebel O.A.U offices (Mahadi, 1986:265). Fernando Po also demonstrated her love for the Slogan 'One Nigeria' when the new president Francisco Marcia Nguema stopped the activities of the International Committee of the Red Cross (ICRC) on the Island in January, 1969. According to Mahadi (1989:267) "we suspected their [ICRC] commitment to humanitarian action was not genuine. We wanted to respect the sovereignty of our friendly next door neighbor".

The point being made is that given the pro-federal military Government posture of the neighbouring countries especially Cameroon and Equatorial Guinea, the minorities of the former Eastern Nigeria found it expedient to migrate en masse (although there is no available statistics) to these countries for safety and security. The evacuation of the minorities between 1975/76 in the post independence era can bear eloquent testimony to this assertion. They indeed formed the majority of labourers in the cocoa plantations. Their expulsion was sequel to the diplomatic row between Nigeria and Equatorial Guinea. Equatorial Guinea was accused of killing and expelling Nigerians from their country as well as having dealing with the racist Southern Africa (Okoro, 2002:98). A bulk of the Ogoni returnees was given settlement farms akin to the ones in Fernando Po at EbubuEleme in Rivers State by the State Military Government (Ziinu, 1993:103).

The main thrust of our discourse is that the Nigerian Civil War, other than the pre-colonial desire to exploit the natural resources of the neighbouring countries and the colonial forced Labour policy, led to the massive exodus of the minorities of the Eastern Nigeria to the neighbouring countries so as to avoid the sledge hammer of hostilities, hunger, atrocities and death.

\section{Conclusion And Recommendations}

We have in this paper looked at the causes of the Nigerian Civil War and discovered that oil was a major causative factor. We revealed that the recaptured of Bonny, Port-Harcourt and Calabar by the federal troops played an important role in the prosecution and subsequent victory in thewar. On the other hand, the loss of these strategic places and other border communities by the secessionist Biafra to the federal Government made the former to be landlocked both on sea and land. This caused the Biafra Republic to surrender as the much vaulted last man could no longer fight. We also elucidated the plight of the minorities in the overcrowded and poorly maintained Refugees camps and food distribution centres. It was glaringly obvious that the minorities therein were marginalized, exploited and forcefully recruited into the military service of Biafra against their will because 
of their powerlessness occasioned by their insignificant number. This unequal treatment pictured the Nigerian state as one which the majority is against the minority.

This paper also exposes the complex multiple interplay of factors that stood against the solidarity, unity and purpose of the minorities of the former Eastern Nigeria. The political leaders of these minorities were polarized and divided between the Biafra and Federal Government ideological politics leaving the minorities at the mercy of the devastating claws of war and some were out rightly imprisoned or shot by the rebel forces. Being abandoned to their fate, the minorities migrated across the borders to neighbouring countries with the aid of locally assembled canoes. This paper also showed that the minority refugees did not only out-number the locals but also formed the bedrock of the economy of the host country. Based on our analysis, we hereby recommend that:

A) Since the defeat of the secessionist Biafra we observe there are still agitations for self-determination necessitating the clamour for national for a sovereign national conference, it is needful for Nigerians and their leaders to look inward and sort out fundamental issues of corruption, ethnicity, lack of patriotism, injustice, politics of exclusion, among others, that heralded the birth of the civil strife.

B) We call on Nigerian leaders to eschew self, party or regional interest and ponder on the things that will further unity, peaceful co-existence and patriotism so as to take Nigeria to greater height. For this reason, we join Achebe $(2012: 258)$ to invite our political leaders to emulate the shining examples of Nelson Mandela who selflessly fought for the liberation of South Africa from the iron grip of apartheid.

C) Minority ethnic groups in Nigeria are yet to be adequately represented in the socio-economic and political areas even when the Ijaw, a south-south minority ethnic group he produced the president in the person of Dr. GoodluckEbelle Jonathan, they are left on the periphery even as they produced the bulk of what sustains the Nigerian economy. The minority should be treated as equal part of the Nigerian system. Nigeria like other federal states should jettison the politics of majority - minority and adopt true federalism, just as Awolowo (1947) has earlier warned "... under a true federal constitution each group, however small, is entitled to the same treatment as any other group, however large.Opportunity must be afforded to each to evolve its own peculiar political institution" (Cited in Saro-Wiwa, 1989:52).

D) While we sue for peace, we passionately call on all the Igbo and those concerned to forget the past, make peace with all Nigerians and avoid divisive tendencies. After all, Gowon had shown compassion and magnanimity in trump by declaring 'no victors, no vanquished', which was suppressed in many civil wars in recorded history. There were no summary trails and executions. Some military officers who served on the Biafra side were absorbed into the Nigerian Army no matter the level of treason charges. Civil servants who fled to Biafra at the outbreak of the hostilities were also absorbed into the federal civil service. The Biafra war Lord, Ojukwu, was not tried but granted state pardon in 1983. He was conveyed from Abidjan to Lagos in a presidential jet. The Ibo, in actual fact, should be able to proclaim the gospel which Forsyth $(2011: 101)$ calls "the war is over".

E) We commend the heroic role played by the international Relief Agencies but at the same time we urge Nigerian Government to depend less on these organizations in order to safeguard her national interest. This is because, as Carvenka (1972:112) noted, the US humanitarian Intervention in the Nigerian civil war had distinctly political implications. Certainly, to meet the humanitarian and emergency aid of Nigerians since international aid are not without condition, Nigerian Government should adopt economic policies that are geared towards selfreliance in the Comity of Nations.

\section{References}

[1]. Achebe Chinua (2012). There was a country, a personal History of Biafra London: penguin Books ltd.

[2]. AdemoyegaAdewale (1981). Why we struck the Story of the First Nigerian coup Ibadan: Evans Brothers (Nigeria publishers) Limited.

[3]. Afolabi, M.A. (2006). Inter-Group Relations in the $20^{\text {th }}$ century Nigeria: A Historical survey in Akinwunmi, O. et al (eds.). InterGroup Relations in Nigeria During the $19^{\text {th }}$ and $20^{\text {th }}$ centuries. Mukurdi: Aboki publishers

[4]. Akinyele, R. T. (1996). "States creation in Nigeria: The Willink Report in Retrospect" in African studies Review 39 (2)

[5]. Akpan, N. U. (1989) "The Position and Role of Nigeria's Ethnic Minorities in War and Peace" in Tamuno, T. N. and Ukpabi, S.C. (eds.) Nigeria Since Independence the First 25 years Volume VI the Civil War years. Ibadan: Heinenamm Educational Books (Nigeria) Ltd

[6]. Anokari, N. B. (1986). Nigerian Inheritance A History of the Ogoni. Port Harcourt: Ano Publications company APC.

[7]. Barron, M. L. (ed) (1967). Minorities in a changing World. New York: Alfred A. Knopf 
[8]. Coleman, J. (1958). Nigeria: A Background to Nationalism. Berkeley: University of California press.

[9]. Elaigwu, J. I. (2011). Topical Issues in Nigeria's political Development Jos: Ala publishing House.

[10]. Elaigwu, J. I. (2009) Gowon Jos: Aha publishing House Limited.

[11]. Encyclopedia Americana (2002), International Edition volume 23 Grolier International IncConnecticum

[12]. Enemugwem, J. H. (2002). "The Civil War Years" in Alagoa, E. J. and Derefaka, A. A. (eds.) The land and people of Rivers State: Eastern Niger Delta. Port Harcourt: Onyoma Research Publications.

[13]. Ekhator, G. O. (2012). "Ethnicity and the Challenged of National Integration in Nigeria: 1960-1999" in V. O. Edo and E. F. K. Salami (eds) Issues and Trends in Nigeria's Development. A Festschrift for the Rev. (Fr) Abiodum F. Akinsey Ibadan: John Archers publishers Limited.

[14]. Fartley, J. E. (1995), Majority - MinorityRelations. New Jersey prentice

[15]. Forsyth Frederick (2011) Emeka Abuja: spectrum Books Limited.

[16]. Helton, A. C. (2000). "Forced Displacement Humanitarian Intervention and sovereignty" in SAIS Review X4(1) spring

[17]. Ikein, A.I (1991).The Impact of oil on a Developing country: The cases of Nigeria. Ibadan: Evans Brothers (Nigeria) Publishers. Ltd.

[18]. Leo, A. D. (1995). Ethnicity and Resource Completion in Plural Societies. The Hague and parts: Mouton publishers

[19]. Marshall Gordon (2001). The Concise Oxford Dictionary of Sociology. Oxford and New York: Oxford University press

[20]. MahadiAbdullahi (1989). "The Roles of Neighbouring Countries in the Nigerian Civil War" in Tamuno, T. N. and Ukpabi, S. C. (eds.) Nigeria Since Independence the First 25 Years Volume VI The Civil War years Ibadan: Heinemann Educational Books (Nigeria) Ltd.

[21]. Mohammed, S. Z. (1989) "Relief services in the Nigerian Civil War" in Tamuno, T. N. And Ukapabi, S. C. (eds.) Nigeria Since Independence

[22]. N-Ue, U. S. (2012) "Niger Delta Struggle Between Isaac and Jasper AdakaBoro and Kenule Beeson Saro-wiwa: Lessons for the future of the Niger Delta" in Journal of Social and Policy Research 7 (3) September 2012 CEDAF

[23]. N-Ue, U. S. (2012)"The Ogoni and her Ndoki/Annang/Ibibio Neighbours from Early Times to 1967" A Thesis submitted to the school of Graduate Studies, Department of History and Diplomatic Studies, University of Port-Harcourt, Nigeria.

[24]. Naannen Ben (2002) "State Movements" in Alagoa, E. J. and Derefaka, A. A. (eds.) The Land and People of Rivers State: Eastern Niger Delta. Port Harcourt: Onyoma Research publications.

[25]. Nwajiaku - Dahou Kathryn (2008) "Remembering And Forgetting Isaac Boro: Multiple Stands in contemporary IjoNationlism" in DerefakaAbiAlabo and Okorobia, Atei Mark (eds.) History Concourse 2007 the Future of the Niger Delta: The search for a Relevant Narrative Port - Harcourt: Onyoma Research publications.

[26]. Nwankwo, A. A. (1980). Nigeria: The challenge of Biafra Enugu: Fourth Dimension Publishers.

[27]. Ogbemudia, S. O. (1991) Years of Challenge Ibadan: Heinemann Educational Books (Nigeria) Plc.

[28]. Ogbogoro, C. B. N (2006) "Nigeria-Niger Delta Relations 1960-1995" in Akinwunmi o et al (eds.). Inter-Groups Relations in Nigeria During the $19^{\text {th }}$ and $20^{\text {th }}$ centuries. Makurdi: Abiki publishers

[29]. Ojukwu - OdumegwuEmeka (2011) Because I am involved. Ibadan: Spectrum Books Ltd.

[30]. Okoro James (2002) Understanding Nigerian Foreign Policy.Calabar: CATS publishers.

[31]. Osaghae, E. E. (1994). Ethnicity and its Management in Africa. Lagos: Malthouse press

[32]. OsuntokunAkinjide (1989) "Review of literature on the Civil War" in Tamuno, T. N and Ukpabi, S. C. (eds.) Nigeria Science independence. The first 25 years Volume VI The Civil War years Ibadan: Heinemann Educational Books (Nigeria) Ltd.

[33]. Saro-wiwa Ken (1989).On a Darkling plain.An account of the Nigerian Civil War. Port Harcourt: Saros International Publishers

[34]. Seymour - Jones Carole (1992).Past and Present Refugees. London: Heinemann educational Books Ltd.

[35]. Simpson, G. E. and Yinger, J. M. (eds.) (1963).Racial and Cultural Minorities: An Analysis of Prejudice and Discrimination. New York: Harper and Row.

[36]. Suberu, R. T. (1999). Ethnic Minority Conflicts and Governance in Nigeria. Ibadan: Spectrum, Books Ltd.

[37]. Stavehagen, R. (1983). The Ethnic Question and the Social Sciences. Journal of cultural and Ideas 9 (3)

[38]. Tamuno, T. N. (180). "British Administration in Nigeria in the Twentieth century" in Ikeme O. (ed.) Groundwork of Nigerian History. Ibadan: Heinemann.

[39]. The Holy Bible (1979) China: Holman Bible Publishers

[40]. The New Encyclopedia Britannica (2003) London: International IncConnecticum

[41]. Yetman, N. R. (1991) Majority and minority: The Dynamics of race and Ethnicity in American life $4^{\text {th }}$ Edition. Boston: Allyn and Bacon.

[42]. Ziinu, N. M. (1993) Ogoni and the Forces of Change 1800-1960. A Thesis submitted to the School of Graduate Studies. Department of History and Diplomatic Studies, University of Port Harcourt 